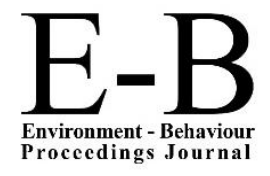

\title{
AcE-Bs2016Taipei
}

$7^{\text {th }}$ Asian Conference on Environment-Behaviour Studies National Taiwan University, Taipei, Taiwan, 09-10 April 2016

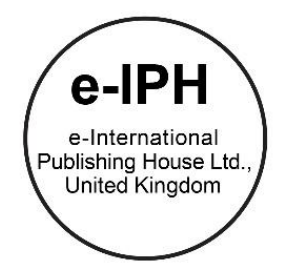

\section{Grey to Green: Rehabilitation of urban dump site through regenerative landscape design}

\author{
Sharifah Khalizah Syed Othman Thani ${ }^{1,2 *}$, Noorjannah Abdul Rahim², \\ Nik Hanita Nik Mohamad², Nor Hanisah Mohd Hashim ${ }^{3}$

\begin{abstract}
${ }^{1}$ Centre for Environment-Behaviour Studies, Faculty of Architecture, Planning and Surveying, UiTM Shah Alam, Selangor, Malaysia
${ }^{3}$ Centre of Studies for Park and Amenity Management, Faculty of Architecture, Planning and Surveying, UiTM Shah Alam, Selangor, Malaysia
\end{abstract} \\ ${ }^{2}$ Centre for Landscape Architecture, Faculty of Architecture, Planning and Surveying, UiTM Shah Alam, 40000 Selangor Darul Ehsan, Malaysia
}

\begin{abstract}
Attempt to rehabilitate the degraded land has been made, and has evidenced many successful redevelopments atop of the land. This paper attempts to look into the specific role of landscape architects in remedying the former dump site. The conceptual design by using principles of the regenerative landscape has been experimented through the proposed remediation of ex-landfill in Mukim Krubong, Malacca. Utilisation of the tropical plant species as an adaptive mechanism to ecologically remedying the contaminated land has been identified. It is hoped that the findings of this paper could contribute to expanding knowledge for sustainable landscape regeneration.
\end{abstract}

(C) 2016. The Authors. Published for AMER ABRA by e-International Publishing House, Ltd., UK. This is an open access article under the CC BY-NC-ND license (http://creativecommons.org/licenses/by-nc-nd/4.0/).

Peer-review under responsibility of AMER (Association of Malaysian Environment-Behaviour Researchers), ABRA (Association of Behavioural Researchers on Asians) and CE-Bs (Centre for Environment-Behaviour Studies), Faculty of Architecture, Planning \& Surveying, Universiti Teknologi MARA, Malaysia.

Keywords: Regenerative landscape design; urban dump site; rehabilitation; Mukim Krubong ex-landfill

\section{Introduction}

In Malaysia, brownfield is defined as an area that has been developed, but abandoned or neglected, or which has a development structure that is already obsolete or a development area that is not entirely completed and abandoned (Department of Town and Country Planning Peninsular Malaysia 2012). As a result of rapid urban growth development and increasing populations, the more amount of trash accumulated is escalating. After the landfill was closed and abandoned, the wastes need to be treated accordingly in order to avoid leaking of methane

\footnotetext{
* Corresponding author. Tel.: +0-000-000-0000

E-mail address: khalizah81@gmail.com
}

2398-4287 @ 2016. The Authors. Published for AMER ABRA by e-International Publishing House, Ltd., UK. This is an open access article under the CC BY-NC-ND license (http://creative commons.org/licenses/by-nc-nd/4.0/).

Peer-review under responsibility of AMER (Association of Malaysian Environment-Behaviour Researchers), ABRA (Association of Behavioural Researchers on Asians) and CE-Bs (Centre for Environment-Behaviour Studies), Faculty of Architecture, Planning \& Surveying, Universiti Teknologi MARA, Malaysia.

DOI: http://dx.doi.org/10.21834/e-bpj.v1i3.364 
gas and leachate pollution. Miller (2006) adds, 'the land perceived contamination problems and require intervention to bring them back to beneficial use'. According to Regeneration of European Sites in Cities and Urban Environments (RESCUE 2005), brownfield regeneration is defined as 'the management, rehabilitation and return to beneficial use of brownfield in such a manner to ensure the attainment and continued satisfaction of human needs for present and future generations in environmentally sensitive, economically viable, socially and institutional robust acceptable ways within the particular region context.' Following Lafortezza et al., brownfield remediation requires particular attention to the effects of ecology and visually because the area is often derelict, undervalued or misunderstood (2008, p. 258). In such situation, Beardsley (2000) says the designer is responsible for determining what needs to be retained, transformed and replaced. When used for landscape design, Hansman (1987) add, long term maintenance costs will be reduced, participation and freedom of user on the nature conservation will be enhanced.

\section{Prevalent issues in Malaysia}

According to Shaaban (2008), the author of the Landfill Common Method and Practices of Solid Wastes Disposal in Malaysia, landfilling or dumpsite in Malaysia is preferable as compared to other waste disposal method due to the low cost and availability of land. Majority landfills in Malaysia are open dump sites without any protection to the environment. According to (John E. Kissida and Spieler, 2010), the surroundings became unsafe as it invites parasites and diseases and becomes threats to public health and safety. According to Ministry of Housing and Local Government, there were 176 active landfills in Malaysia. A study shows that Kuala Lumpur, the capital city of Malaysia, could only provide 0.4 hectares of open spaces per 1,000 urban populations (Ismail, 1999). Comparative analyses in 2004 (Ministry of Housing and Local Government 2004) and 2012 (National Solid Waste Department 2012) showed the increase in quantity and urban space coverage of former landfill in Malaysia. The former landfills became an issue that sparks worries to the local communities on their societal well-being (Chun-Yang \& Talib 2006, Brender et al. 2011). In City Form and Natural Processes, Michael Hough (1984: p.2) add, the presence of a contaminated sites that have been abandoned can negatively impact to the local environment and social welfare. Environmental pollution can affect the human health, our biodiversity, air and water quality. In addition, contaminated sites can give impacts on the loss of land and aesthetic value in the neighbourhood area (Neupane and Gustavson 2008). The quality of landscape (in the context of the 'environmental impact assessment' procedures) which is often considered as a second range issue in the context of brownfield regeneration where new landscapes must be restored or rebuilt (Collier \& Scott, 2008 in Christine Ruelle, 2012). A landscape architect could help in creating stewardship policy of micro-Eco disaster which then becomes eco-restoration sites.

\section{Objective of the study}

To investigate the best landscape architecture approaches and design that provides remediation of former landfills in Malaysia by integrating both engineering and green approaches.

\section{Significance of study}

Living in close vicinity to former landfill commonly associated with a perception of a reduction in health and safety status and deterioration of the surrounding living environment (Azahan, 2015). Amidst those issues, the existence of former landfills has been identified as assets to address the issue of urban space for the future development (Department of Town and Country Planning Peninsular Malaysia 2010) and the insufficient urban green space provisions according to the standard of 2 hectares per 1,000 urban populations (National Landscape Department 2010). Landscape architects could played a main role in the community in turning the "brown" and "grey" site, became a productive use of the social and economic benefit. It can economically enhance the neighbourhood as businesses investment as people settle in neighbourhoods they find attractive (De Sousa, 2006a). Landscape architects may affect the use and misuse of resources while integrating thoughtful design strategies. Contributing to 
the protection of existing ecosystems, landscape architects played a role in a regenerating ecosystem that has been damaged. The appearance of an area could affect the attitudes and perception of investors towards a community, which can be changed even a small enhancement, is made (Kuo et al. 1998).

\section{Methodology}

\section{Primary data}

Site observation was conducted to analyze and explore the existing site chosen and quality. Photos were taken in order to ascertain notable aspects of the site features. The findings will be further analyzed to identify the important physical and environmental attributes.

\section{Secondary data}

Secondary data was collected from data given by local authorities which are Jabatan Perancang Bandar, Bahagian Kawal Selia and Bahagian Landskap, Jabatan Pengindahan Bandar and Jabatan Perancang Bandar, Majlis Bandaraya Melaka Bersejarah (MBMB), Jabatan Perancangan Bandar dan Pembangunan Landskap, Majlis Perbandaran Hang Tuah Jaya (MPHTJ). The authors also obtain information from Jabatan Pengurusan Sisa Pepejal Negara (JPSPN) for detail information regarding site management.

\section{Reference cases}

\section{Tianjin Qiaoyuan Park, Tianjin, China - The Adaptation Palettes}

Tianjin Qiaoyuan Park covered 22 hectares (54 acre) was formerly a peripheral shooting range which that turned into a waste disposal area, drainage sink for urban storm water, surrounded by slums and temporary rickety structures, due to rapid urbanization surrounding it. The area was densely populated on south and west and bounded of highway and an overpass on west and north. The area was once rich in salt marshes and wetlands make the soil quite saline and alkaline. In early 2003, Tianjin municipal government contracted the landscape architect to start the immediate transformation of this degraded site in response to residents' call for environmental improvement of the site. This project is to provide a diversity of nature's services for the city and the surrounding urban residents, including containing and purifying urban storm water. One of design strategy is improving the saline-alkali soil through natural processes; recovering the regional landscape with low-maintenance native vegetation; providing opportunities for environmental education about native landscapes and natural systems, soil improvement, landscape sustainability; and creating a cherished aesthetic experience. Adaptation palette has been selected as the overall construction of a park concept to give the opportunity to the nature to work. Simple strategies are made, by digging 21 ponds with different diameter from 10 to 40 meters and depth from one to five meters which then gives different effect during rainy season. From that, the saline-alkaline soil gradually improved while nutrients seeped into the pond. During certain seasons, there are plants that thrive well in some patches which suits the vegetation that is sensitive to regional water and alkaline-sensitive soil.

\section{CyPark Resources Berhad (CRB), Malaysia}

Cypark Resources Berhad is a company that provides specialized services in providing integrated renewable energy and environmental engineering through: Integrated renewable energy generation (solar, biogas, biomass, waste-to-energy), Waste management Environmental remediation (i.e. landfill restoration), Sustainable Environmental Restoration (SER), Scientific closure and remediation of contaminated land through internally developed technology (COLARIS), Groundwater assessment, remediation and information system (GARIS), Environmental monitoring and management, as well as Wastewater treatment. When the methane gas was not 
enough to generate energy, Cypark will completely depend on solar panel project. Recently, Cypark want to optimize use the area of park by planting edible plants below the solar panel such as chillies and rock melon either to be produce to another product or exported. Then the plants will be process to make sauce, jam and also cordial. The main objective to remediate landfill is to protect human health and the environment, eliminating airborne vectors, air, soil and water pollution as well as major problems caused by open dumping.

Table .1 Business and Area of Expertise of Cypark Resources Berhad, Malaysia

\begin{tabular}{|c|c|c|}
\hline $\begin{array}{l}\text { Contaminated Land Assessment, Remediation and } \\
\text { Information System (COLARIS). }\end{array}$ & $\begin{array}{l}\text { Sustainable Environmental } \\
\text { Restoration (SER) }\end{array}$ & $\begin{array}{l}\text { Groundwater Assessment, Remediation } \\
\text { and Information System (GARIS) }\end{array}$ \\
\hline $\begin{array}{l}\text { As the initial remediation and treatment system which } \\
\text { provides assessment and remediation services related to } \\
\text { contaminated and dump sites. It is divided into two } \\
\text { components: } \\
\text { - Contaminated Land Site Assessment } \\
\text { (Carried out to determine the condition of the site and } \\
\text { surrounding areas before any activities implemented) } \\
\text { Remediation } \\
\text { On-site remediation (in situ zone remediation, } \\
\text { containment, protection, pathway prediction and fate of } \\
\text { off-site receptors) } \\
\text { Off-site remediation (zone remediation, containment } \\
\text { and protection) } \\
\text { Special collection and disposal services (on-site and } \\
\text { off-site soil treatment). }\end{array}$ & $\begin{array}{l}\text { Hazardous dumpsite and } \\
\text { contaminated areas would be } \\
\text { restored and transformed into } \\
\text { economic and social value. }\end{array}$ & $\begin{array}{l}\text { An in-house development process will carry } \\
\text { out on detailed assessment and testing } \\
\text { towards the impact of groundwater pollution. } \\
\text { Remediation will be done according to the } \\
\text { design developed using the assessment, to } \\
\text { provide environmental assessment and } \\
\text { mitigation process to protect ground water } \\
\text { resources from contamination. }\end{array}$ \\
\hline
\end{tabular}

\section{Case study}

The data collection for this study area and existing elements has been done through inventory and analysis method. Krubong is one of the districts in Melaka Tengah District. The location of Krubong Former Landfill is along Sungai Melaka covering 167 acre (69 hectare) of land area. According to Bahagian Kawal Selia, Majlis Bandaraya Melaka Bersejarah (MBMB), the site was previously is the swamp forest planted with close Nypa fruticans and Melaleuca leucadendra trees. In 2011, MBMB has worked with selected companies from Japan that have been given the concession to manage the production of Methane Gas from the old landfill area, namely, Kajima Corporation, Mitsui Co. Ltd., and also Southern Waste Management Sdn. Bhd from Malaysia.
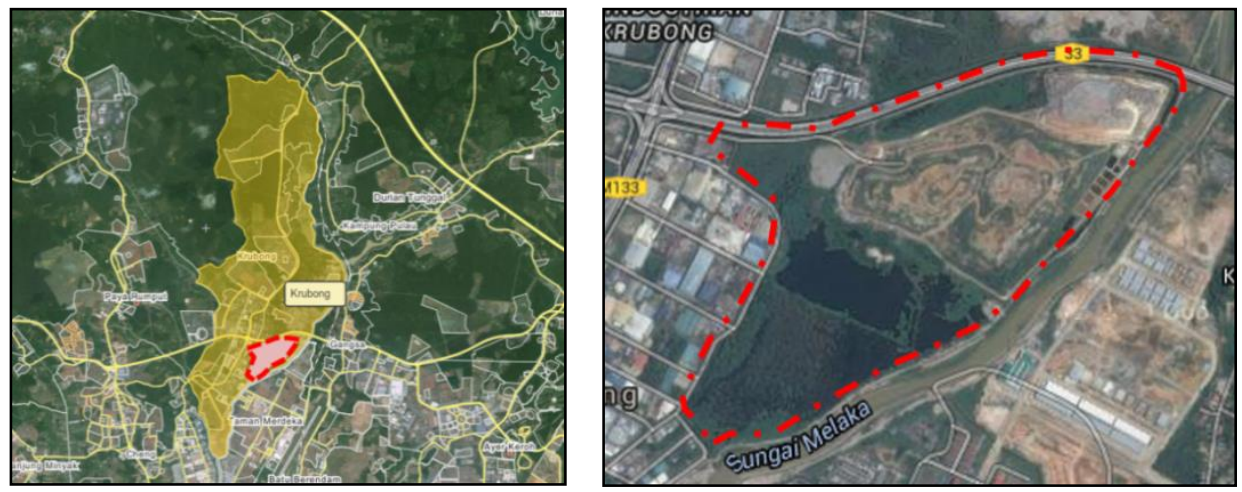

Fig. 1(a)District Plan - Mukim Krubong; (b) Site Plan - Former Landfill Site (Source: Google Map \& Pejabat Daerah dan Tanah Melaka Tengah, 2015) 
The existing elements consist of constructing, natural and processing materials; the constructed element (MBMB's old offices), the natural element (landfill site) and processing element (the leachate plant station).

\section{Leachate contamination}

Landfill site is normally associated with leachate formation, which is a product of compression of trash, and degraded by biological and physicochemical microbial activities. The trash then degrades into organic fraction combined with percolation of rain water. The black liquid that is present in a landfill area contains organic and inorganic chemicals as well as heavy metals, pathogens that can pollute groundwater and cause health risk (Osterath, 2010).

Smell pollution

Presently, methane gas at the Old Landfill site is channeled out using flare system. In Landfill Site 2, the methane gas is still present because of it was only recently closed. Just like leachate contamination, methane gas has been the byproduct of landfill sites which could be beneficial or harmful to human being. In Landfill Site 2, the smell of methane gas is strong as the gas is released naturally into the air. Moreover, a few residential areas are located near the landfill site. They should not be built near the landfill area in the first place due to human safety, health, social and environmental impact. The problem may be solved by adding more scented plants, increasing the width and compactness of the buffer strips and managing the methane gas from LFG System.

The former landfill has become the scarcity of land when it covers a wide space for dumping site. As land becomes more valuable, reuse of abandoned or derelict land - including former landfills - is becoming more widespread. Landfills provide unique opportunities for reuse, although significant development limitations must be addressed. The design aims to regenerate the land for other future development by remedying the former landfill site and bring back into the ecosystem that has been polluted. The objectives of landfill remediation design by ecological approach are to determine the use of plants in different stages and techniques not just to beautify the place, but also act as a green mechanism to recover the place and restore the habitat. It also offers a bio - solution for cleaning up (rehabilitate) the existing contaminated areas.

\section{Design guidelines - design approach}

The intention of design guidelines is to propose the best approach to be implemented on site. There are a few guidelines, provided that are according to local government and agency requirements. These include Soil Capping Process, Landfill Gas Flare System (LFG), Bioindicator, Microbiological Treatment - Biofiltration, Revegetation Remediate Action for Landfill, and Phytoremediaiton.

\section{Soil capping process}

This process will take place as the first remedial action that need to be taken when the landfill is officially closed. Capping design and construction are comprised of engineering and restoration layers. The capping technique also minimizes infiltration of water into the waste, control gas mitigation, as a physical separation between waste and plant and animal life and also promotes surface drainage and maximize runoff. The main soil problem with the site is, the soil depth is not suitable for root development because it is too shallow and rocky. Moreover, not all kinds of plants can survive in contaminated soil. For upper level of landfill, it is important to add top soil with suitable soil medium to increase the nutrient level. Organic and nutrient testing need to be conducted to support planting so that the solution and nutrients needed to add to the soil can be identified. If the soil is higher in acidic level, lime is used to ensure the soil pH level is about 6 to 8 . If the soil is low in nutrient level, nutrient sources are added to encourage plant growth. The overall thickness of nutrient level must be 15 millimeters. To reduce soil compactness, upper layer need to be done manually to loosen the texture. For upper level, the soil thickness is 0.75 meter thickness, which is not suitable. Another 1.25 meter thickness is added to reach the minimum of 2 metres. 


\section{Bioindicator}

A bioindicator is a living organism that gives an idea of the health of an ecosystem and can be divided as microbial, plant or animal indicator, that is used to monitor the health of the environment. Plant species can be used to indicate various types of soil by monitoring their establishment in certain areas. Some animal indicators are very sensitive to pollution in their environment. They may change their morphology, physiology or behaviour, or they could even die if pollutants are present. For an example, algae is suitable to be used as an indicator for water quality assessments when there is excessive release of nutrients such as nitrates and phosphates.

\section{Microbiological treatment - bioremediation}

According to Vidali (2001), microbes can thrive in isolation in almost all environmental conditions. Bioremediation is any process that uses biological agents, mainly microorganisms (yeast, fungi, or bacteria), green plants or their enzymes to break down harmful chemicals and pollutants in the environmental improvement measures. It is a natural way to clean up contaminated soil and water (Strong and Burgess, 2008). Microorganism cannot break down and destroy heavy metal, but can affect their physical and chemical character through migration and transformation (Zhitong Yao, 2012).

\section{Revegetation - remediate action for landfill}

Many landfills or reclaim places have been revegetated with a variety of plants. One of the important concern is, the potential of roots that penetrate and physically damage the cap, thus can create the entry points for water, or even open fissures in the protective barrier by excessive reduction of humidity. In a period of time, if the plant composition is designed properly, the landfill surface integrity can be maintained and supports a variety of plants. Native plants are used as remedial agents because, it can develop into a self-sustaining ecosystem, eliminate the need of fertilizer, pesticides and water, has low maintenance cost, is naturally adapted to site-specific conditions, is long-lasting, and stress tolerant. Native plants are alternatives to provide erosion control, stabilize the soil, provide habitat, have low maintenance cost, and absorb more carbon. Redevelopment of contaminated sites into green space is valuable because it can improve the quality of soil, improve recreational opportunities and generate neighbourhoods economy (Loures and Panagopoulos 2007). Studies show that the community's psychology has positive effect when vegetated public space brings community together, through their participation in the development of the place by utilizing it to a usable space.

\section{Landfill Gas Flare System (LFG System)}

Purposes for landfill gas collection is to prevent off-site subsurface LFG Migration, to reduce surface emissions, protection of groundwater, odour control, protection of cover and generate revenue.

\section{Phytoremediation}

Phytoremediation is used to rehabilitate polluted landscapes that must be cleaned up before future development can be done on the land. There are numerous evidence from field and laboratory test that show the trees and other plants are able to absorb, convert or contain a variety of contaminants include soft and heavy metals, volatile organics by hydraulic control, and absorption and mycorrhizal activity in the root zone (Isebrands, 2003). The methodology is simple where plants are used to treat and purify the contaminated land by absorbing contamination. The difficulty is identifying which plants have the ability to absorb certain chemicals and the exact time the process will take place (Avis, 2015). Sleegers (2010) evaluated that "phytoremediation as a process-oriented mechanism to expand the green network infrastructure that determines the new landscape". Phytoremediation used to rehabilitate polluted landscapes that must be cleaned up before future development can occur on the land. 
Table 1. Phytoremediation mechanism (Adapted from Isebrand, 2011)

\begin{tabular}{|c|c|}
\hline Inorganic Process & Organic Process \\
\hline Phytostabilization & Rhizodegradation \\
\hline $\begin{array}{l}\text { Root immobilize contamination in the soil. It reduces soil and } \\
\text { wind erosion of contamination. }\end{array}$ & $\begin{array}{l}\text { Plants root provide the beneficial environment for microbes that in } \\
\text { turn break down organic contamination in the root zone. }\end{array}$ \\
\hline Rhizofiltration & Phytodegradation \\
\hline Plants absorb contamination into the root. & $\begin{array}{l}\text { After the plants absorb the organic contaminants, plant enzymes } \\
\text { break down the contaminants to safer compounds. }\end{array}$ \\
\hline Phytoextraction & Phytovolitalization \\
\hline $\begin{array}{l}\text { Roots absorb contaminants into the upper parts of plants. } \\
\text { (Leaves, branches and stems) }\end{array}$ & $\begin{array}{l}\text { Plants take up contamination and release a safer mediated form } \\
\text { of the organic compound into the atmosphere. }\end{array}$ \\
\hline
\end{tabular}

\section{Phytoremediation - advantage and limitations}

Table 2. The advantages and limitations by using phytoremediation process

\begin{tabular}{ll}
\hline Advantages & Disadvantages \\
\hline In situ & Limited to shallow soils, streams and groundwater. \\
High public acceptance - Aesthetically pleasing & Toxicity and bioavailability of degradation products are not known. \\
Costs 10 to $20 \%$ of mechanical treatments. & Slower than mechanical treatments. \\
Passive & High concentration of hazardous materials can be toxic to plant. \\
Fewer air and water emissions. & Contaminants may be mobilized into the ground water. \\
\hline
\end{tabular}

(Source: Chappell, 1997)

Moreover, phytoremediation include the use of the hyperaccumulator plant to remediate the contaminated soil. The advantage of the hyperaccumulator plants is, they are able to uptake large quantities of heavy metals and continue to thrive while storing these heavy metals in their plant tissue. These kinds of plants show the fact that plants can function well on contaminated soil by ecological approach. Though phytoremediation takes a length of time to purify the soil, it integrated a good landscape design strategy that can be beneficial in enhancing urban space and landscape polluted areas into a cleaner place in the future (Avis, 2015).

\section{Riparian buffer strips or vegetative filters}

This method is included in phytoremediation approach. It is used as covers for a landfill alternative to clay or plastic cap. The vegetative filters will be planted between the contaminated area and the riparian zone. It is designed to slow down and reduce the flow of contaminated water and sediments of the contaminated area to the riparian zone.

\section{Conceptual and design development}

The process involves is to indicate the suitable site or area that is most potentially viable based on the guidelines. The design and concept development is the remedying process and planting composition. The concept is focused on how the selected approaches work by specific mechanism. The concept will not neglect the engineering methods that are efficient. Figure 2 depicts the 'Verdant Vitality' which means 'Green Energy' to symbolize how two different mechanisms which are green (plants) and energy (engineering system) work together to remediate former landfill soil to achieve ecological and sustainable approach. 


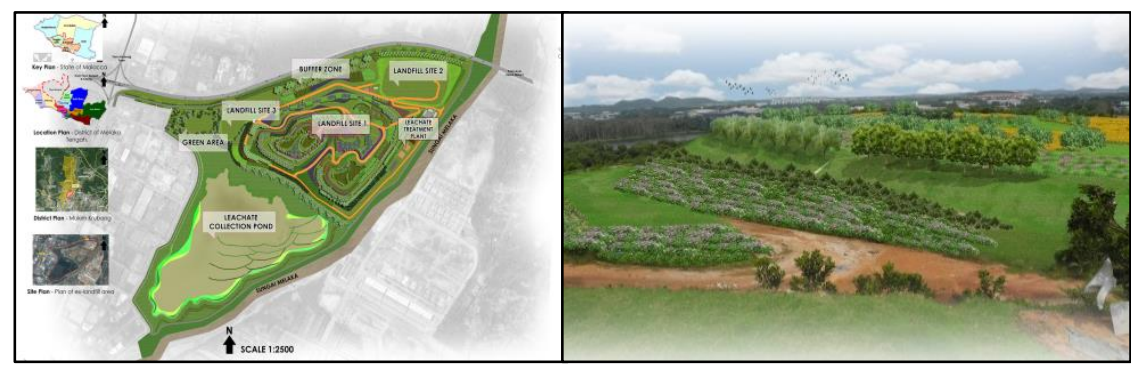

Fig. 2 Master plan and perspective that shows the design concept and development of the Krubong Landfill

\section{Plant matrix}

(Source: Author)

The matrix of plants (in Appendix) concludes the function of plants in remedying the contaminated land by considering the suitability to adapt to our tropical climate. Figure 3 shows the adaptation of certain characteristic and plant types that were chosen based on literature sources and analysis from other researchers could be incorporated into the design.

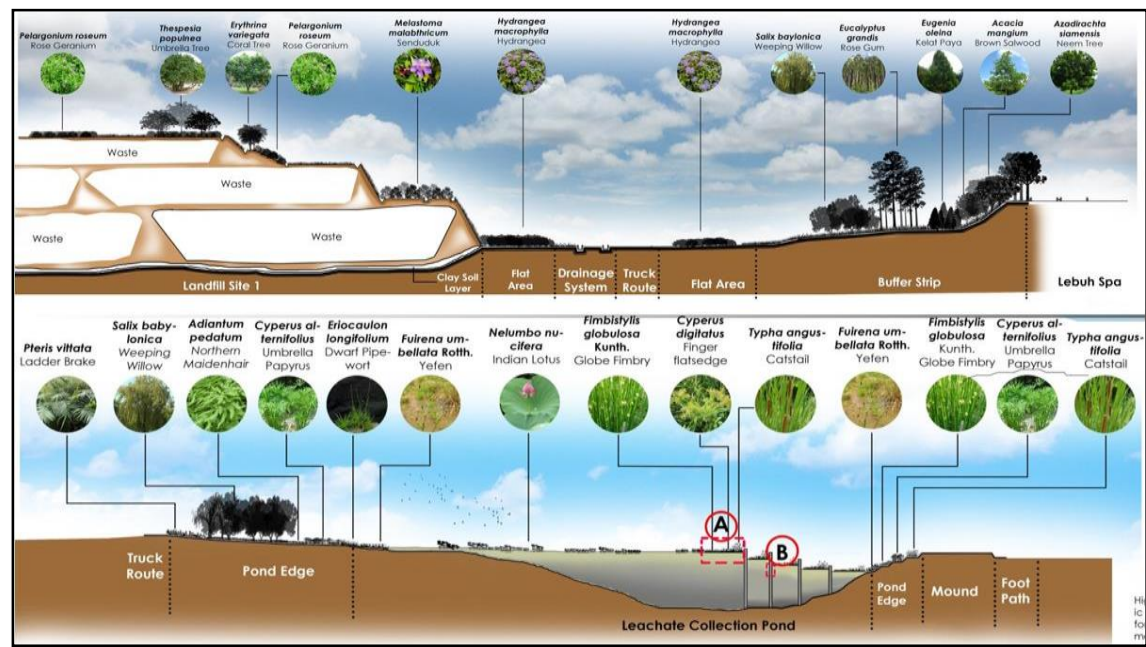

Fig. 3 Cross-section to show how the planting mechanism could be used to remediate the former landfill of Krubong. (Source: Author)

\section{Conclusion}

In general, the landscape architects can play a major role in the rehabilitation of contaminated soil, particularly former landfills, and can provide a positive impact to ecology and biodiversity. The regenerative design approach will not only restore habitat resources, but also treat air and water source. In addition, the suitable selection of plant materials that have high potential for treatment of contaminated soil, with cheaper cost can play an important role in improving the environment.

\section{References}

Avis, K. (2015, September 30). Engineering news - phytoremediation: using plants to remediate land. Retrieved February 3, 2016, from Sourceable - Industry News \& Industry: https://sourceable.net 
Awang, M. S. (2014). Ex-landfill redevelopment and adequacy of open space provision: An integrated approach in Malaysia urban development. developing country studies.

Beardsley, J. (2000). A word for landscape architecture. Retrieved February 2, 2016 from http://www.harvarddesignmagazine.org/issues/12/aword-for-landscape-architecture

Chappell, J. (1997). Phytoremediation of TCE using populus. Status Report prepared for the U.S EPA Technology Innovation Office under a National Network of Environmental Management Studies Fellowship.

Christine Ruelle, J.-M. H. (2012). Landscape quality and brownfield regeneration: A community investigation approach inspired by landscape preference studies. Landscape Research,, 1-25, iFirst article.

De Sousa, C. (2006a). Urban brownfileds redevelopment in Canada: The role of local government. The Canadian Geographer, 50, $392-407$.

General Design ASLA (2010). ASLA Professional Awards. Retrieved September 17, 2015 from American Society of Landscape Architecture: http://www.asla.org

General Design ASLA. (2010). ASLA Professional Awards, Award of Excellence, Shanghai Houtan Park: Landscape as a living system. Retrieved August 27, 2015, from American Societies of Landscape Arcitecture : http://www.asla.org

Gustavson, A. N. (2008). Urban property values and contaminated sites: A Hedonic Analysis of Sydney, Nova Scotia . Journal of Environmental Management, 88, 1212-1220.

Hansman, D. J. (1987). An ecological approach to landscape design in urban parks. (Dissertation).

Isebrands, L. M. (2003). Phytoremediation of Chicago's Brownfields: Consideration of ecological approaches and social issues.

Isebrands, L. M. (2011). Phytoremediation of Chicago's Brownfields: Consideration on Ecological Approaches and Social Issues.

Frances E., \& Kuo, W. C. (1998). Fertile ground for community: Inner-city neighbourhood common spaces. American Journal of Community

Psychology, 26 (6)

Osterath, B. (2010, December 16). Chemviews magazine. Retrieved December 8, 2015, from ChemistryViews: http://www.chemistryviews.org/details/news/886147/Landfill_Leachate_A_Dangerous_Liquid.html

Panagopoulos, L. L. (2007). Sustainable reclamation of industrial areas in urban landscapes. WIT Transactions on Ecology and the Environment, Vol 102, 2007.

Rubin, E. (2006). Revegetating landfills and waste containment area fact sheet. Environmental Protection Agency, United States.

Shaaban, M. I. (2008). Landfill common method and practices of solid waste disposal in Malaysia. Conference Paper.

Sleegers, F. (2010). Phytoremediation as green infrastructure and a landscape of experience. Proceedings of the Annual International Conference on Soils, Sediments, Water and Energey, 15. Article 13.

Spieler, J. E. (2000). Case studies in successful landfill reuse. Cambridge, Massachusetts: CDM.

Strong PJ and Burgess JE (2008). Treatment methods for wine related ad distillery wastewaters: A review. Bioremediation Journal, $12,7087$.

Talib, Y. C.-Y. (2006). Overview of Brownfields in Malaysia. JURUTERA, 16.

Thomas Macek, P. K.-d. (Mar 26, 2008). Novel roles for genetically modified plants in environmental protection. . Trends Biotechnol, 146-152.

Vidali, M. (2001). Bioremediation. an overview. Pure Appl. Chem., 73 (7),1163-1172. IUPAC.

Zhitong Yao, J. L. (2012). Review in remediation technologies of soil contaminated by heavy metals. Procedia Environmental Sciences, 16, $722-$ 729. 
Appendix
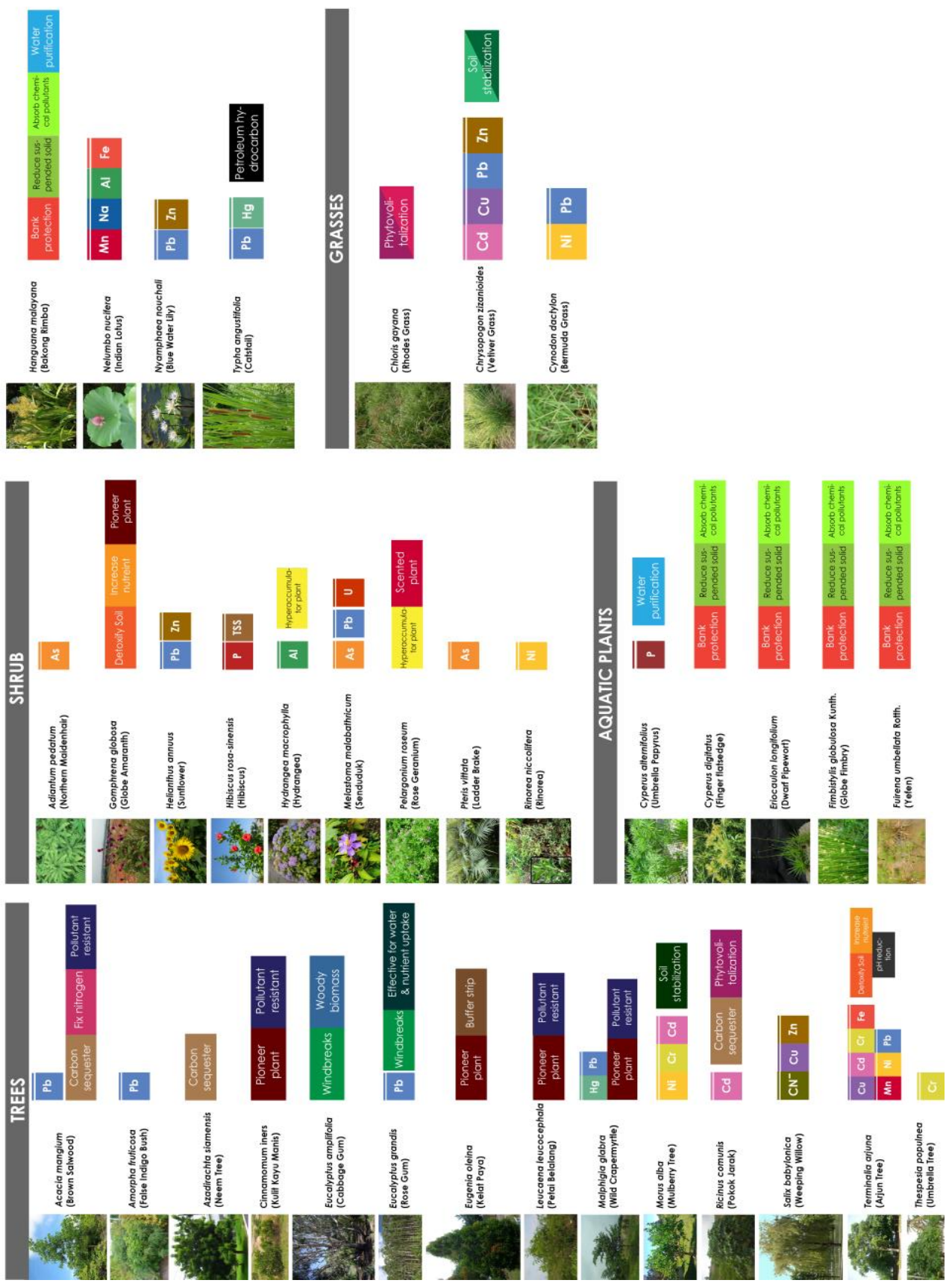